\title{
THE EFFECT OF THE GOOGLE CLASSROOM APPLICATION ON THE STUDENTS' WRITING SKILLS IN SMA SWASTA GAJAH MADA MEDAN DURING COVID-19 PANDEMIC
}

\author{
Irma Khoirot Daulay, Agnes Charismah Iman Putri Zendrato, Jeffry, \\ Neslita Elisabeth Manik, Priska Simamora \\ Universitas Prima Indonesia \\ e-mail: irmaemhum@gmail.com
}

Received: 2021-10-19

Accepted: 2021-11-21

\begin{abstract}
The research aims to determine the effectiveness of applying the Google Classroom Application on the students' Writing Skills from grade X1 of SMA Swasta Gajah Mada Medan. The research applied the quantitative method with experimental design. The data were analyzed using the mathematics system related to the methods applied in the research. According to the research findings, it is concluded that Applying Google Classroom Application potentially gives more effectiveness in teaching writing skills to the students. After the posttest is done, the mean score of applying Google Classroom Application is 85.65 . The standard deviation is 7.353 , and the number of students is 26 . The mean by applying conventional strategy is 62.00 , the standard deviation is 3.943 , and the number of students is 24 . From the research result, the researchers found that the mean score of the experimental group students was improved by 17.10. In the controlled group, the mean score of the students was improved by 9.75. After the post-test by applying Google Classroom Application to the students is undertaken, the normality test result is 0.465 . After a post-test to the students by applying the conventional teaching method in the controlled group is given, the normality test result is 0.243 . The research finding explained that the Google Classroom Application successfully improved the students' writing skills, especially at SMA Swasta Gajah Mada Medan during the Covid-19 pandemic.
\end{abstract}

Keywords: Google Classroom Application, Writing Skills, Narrative Text, Covid-19 Pandemic

\section{Introduction}

As the fourth skill in mastering the English language, writing was the most high level of language skills that everyone must be mastering. Especially for students in English language major, who must be learning and mastering this skill by having the writing result in article publication, news, and writing assignment.

Harmer (2001:79) said that writing is a communication system in delivering thoughts and expressions to people. These thoughts and expressions write so that many individuals can read them. Meanwhile, according to Nation (2009:112), writing is an 
activity that people engage in to maximize their skills, and people must enhance their listening, reading, and speaking skills.

Nowadays, many teachers use Google Classroom Application as a media globally. Many teachers have used this application to teach students online. This application is very recommended to the teachers or the students who want to conduct online learning. The teachers can design online classrooms creatively. The teachers are able can invite more students to join the online class. Then the teachers can create and share the assignments online. Teachers and students can have a good conversation by using Google Classroom Application. They can communicate about the students' progress (Vangi: 2020). Liu and Chuang (2016) explained that a professor or a teacher could interact with the students when online learning. This application can be used in the difference of distances. The professor and the students can interact well when they have class virtually. Using this application, the professor and the students can communicate, discuss, or learn more about material learned by the students.

Firstly, Mike Okmawaty (2020) conducted research. The research focused on analyzing the effectiveness of using Google Classroom Application in teaching online. After applying this application in the learning process online, all the students were interested and could join online learning enthusiastically. During the covid-19 pandemic, the government has recommended the Google Classroom Application as one of the applications that teachers can use in teaching online. Although the government has suggested using the google classroom application to be a means of online learning, the application still has problems experienced by teachers and students. In running the online learning, Google Classroom Application can use with a stable internet connection. If there is no good internet connection, Google Classroom Application cannot use as a medium for online learning activities.

Secondly, M. Khalil (2018) also conducted research related to this topic. After seeing the research result, it can conclude that Google Classroom Application is a choice that can use to teach English, especially when teaching English grammar. Google Classroom Application also could be used as an application where the students could discuss or work together when they had a project. The students could work together when there was a project to be discussed by the students. It means the students can cooperate by using this application. The students could also give feedback to the teachers to evaluate the learning process conducted before. The teachers could obtain many benefits when the teachers used Google Classroom Application to teach the students online and learn and do how to develop the ability to use ICT in the learning process. The teachers could explore many things related to the material taught to the students.

As preliminary data, the students still feel challenged to learn English, especially when learning English Writing. The researchers were able to understand students' ability in writing by seeing the average score. The students' scores were under the KKM (Minimum Criteria of Mastery Learning). The English teachers also explained these findings. The English teachers need an effective way or technique when teaching English material to the students. The researchers researched to maximize the students' writing skills. Relating to these findings, The researchers were interested in undertaking research. The title of this research was "The Implication of the Google Classroom Application Towards the Writing Skills of the Students of SMA Swasta Gajah Mada Medan During the Covid-19 Pandemic. 
After reading the explanation as presented before, The researchers could formulate the problems in this research. The problem of this research can be formulated with "Does Google Classroom Application significantly affect the students' writing skills at SMA Swasta Gajah Mada Medan during the covid-19 pandemic?". Meanwhile, the study's objective was to find the significant impact of the use of Google Classroom Application towards the writing skills of the students of SMA Swasta Gajah Mada Medan during the covid-19 pandemic. The researchers only focused on the implication of using the Google Classroom Application towards the writing skills of SMA Swasta Gajah Mada Medan. Narrative Text chose as the topic for grade XI students' 2021/2022.

\section{Literature Review}

Google Classroom is an application that allows the creation of classrooms in cyberspace. Google Classroom can distribute tasks, assignments submission, and assessments. Google Classroom can download without any charge by registering on the Google account application for education. Google Classroom app is handy for online teaching and learning and can be obtained free of charge and can use on any device. One of the sophistication of this application is that it can be used collaboratively with other groups. There are so many advantages of using Google Classroom as one of the Learning Management Systems (LSM). (Alim et al., 2019). Google Classroom is regarded as one of the best features of Google's web for improving teachers' and students' performance in teaching and learning activities. It has several useful features that make it an ideal device for the scholar. It can save multiple times while keeping the class running. (Ela \& Tatik, 2020).

Linguistics studies are inseparable from the four basic skills that must be mastered: writing. Writing is a language field that requires creativity and good knowledge. Several factors must be applied in writing at once (Daulay, I.K. \& Asrul). Writing skills in English are essential because they enable learners to communicate and express ideas and feelings (Firdaus, 2020). Writing skills are challenging to master. Learning to write is not enough to master grammar and writing theory, but it must be accompanied by practice and guidance. Writing refers to generating or expressing feelings and thoughts using symbols agreed upon between speakers of one language and another (Sidik, 2016: 34).

In gender of text, there is a text, namely Narrative; this text tells a story about something in chronological order to enjoy the text; that is means researchers should be able to style their text in exciting ways. (Daulay, I.K. \& Asrul, 2021). Authors of narratives have to remember what happened, plan and organize events, choose vocabulary, formulate sentences correctly, and at the same time think about several formal aspects such as spelling and punctuation. Speaking comprehension was related not only to oral storytelling skills but also to reading comprehension and school performance. (Jhonson, 2021).

\section{Research Method}

This research had two variables: independent variable (symbolized with $\mathrm{X}$ ) and dependent variable (symbolized with Y). Sugiyono (2013: 61) defined that a variable that can be affected or changed by the dependent variable is called an independent variable. The dependent variable in this research was Google Classroom Application.

SMA Swasta Gajah Madan students from eleventh grade in the school year $2021 / 2022$ were chosen as the research population. The total number of the population 
was six classes. Grade X had two classes, grade XI had two classes, and grade XII had two. Each class had 25-30 students. There were about 150 SMA Swasta Gajah Mada Medan students based on the data.

The researchers did random cluster sampling to get the sample in this research. According to Guy (1992:132), it can be defined that cluster random sampling technique is a way done by the researchers to get the sample from the population and this sample was taken in group and to get this sample was done randomly. The researchers selected all the selected group members who had similar characteristics. The researchers did cluster randomly. The researchers determined this cluster randomly to get two classes. The sample of the research chose from the two classes. After getting the research sample, the researchers randomly determined the classes categorized as the controlled group and experimental group. After that, grade X-IPS was chosen as the controlled group, and grade XI-IPA was chosen as the experimental group.

The researchers first did the pre-test for the students in the controlled and experimental groups. From the data, the researchers knew about students' ability in writing skills. These results were known from the students' control and experimental groups' scores. Next, the researchers did the treatment in the controlled group and experimental group. This treatment was called the post-test. The researchers applied google classroom to the students' writing skills in the experimental group, and the researchers applied the conventional teaching method to the students in the controlled group. After doing the post-test in the controlled and experimental groups, the researchers knew the students' progress in writing skills. If the score of the students were not significantly increased yet, the researchers did the post-test II. The researchers taught the students using google classroom in the experimental group and the conventional teaching method in the controlled group. After doing the post-test, the researchers knew the result. The researchers could compare the scores of students who were taught using google classroom and those who were taught by using conventional teaching methods.

In conducting the pre-test, the researchers did some steps. The researchers made the pre-test objectives, then chose the pre-test method. After that, the writer planned the pre-test. The researchers developed the pre-test guide, developed the questions, and conducted the pre-test. After conducting the pre-test, the researchers analyzed the data and interpreted the result. Lastly, the researchers summarized the results. From the students' score data, the researchers knew how to treat the students in the post-test after doing the pre-test. If the students' scores were low (under KKM), the researchers treated both the controlled and experimental groups.

In the treatment session, the researchers applied a method to improve the students' writing skills. In the controlled group, the researchers applied the conventional teaching method. In the experimental group, the researchers applied google classroom in teaching writing skills. The researchers did the steps of using that method.

In the post-test session, the researchers gave tests to the controlled and experimental students. The tests are in written form. The researchers made the post-test objectives, chose the post-test method, planned the post-test, developed the post-test guide, developed the questions, and conducted the post-test. The researchers analyzed the data of students' scores and interpreted the result. Then the researchers summarized the results of the students' scores in the controlled group and experimental group. The post-test could be done two times or more; it depends on the result of the students in the previous post-test. 


\section{Discussion}

Based on the results of the research that has been done, the following data were found:

\begin{tabular}{|l|c|c|c|c|c|}
\hline \multirow{2}{*}{ Category } & \multirow{2}{*}{ Scores } & \multicolumn{2}{c|}{ Frequencies } & \multicolumn{2}{c|}{ Percentage } \\
\cline { 3 - 6 } & & Pre-Test & Post-Test & Pre-Test & Post-Test \\
\hline Very High & $80-100$ & 2 & 19 & $7.69 \%$ & $73.08 \%$ \\
\hline High & $60-79$ & 22 & 7 & $84.61 \%$ & $26.92 \%$ \\
\hline Fair & $40-59$ & 2 & 0 & $7.69 \%$ & $0 \%$ \\
\hline Low & $0-39$ & - & 0 & $0 \%$ & $0 \%$ \\
\hline
\end{tabular}

Table 1. Descriptive Analysis of Pre-Test and Post-Test in Experimental Group

\begin{tabular}{|c|c|c|c|c|c|c|c|c|c|}
\hline \multicolumn{2}{|c|}{ Mean } & \multicolumn{2}{c|}{ Median } & \multicolumn{2}{c|}{ SD } & \multicolumn{2}{c|}{ Max } & \multicolumn{2}{c|}{ Min } \\
\hline $\begin{array}{c}\text { Pre- } \\
\text { Test }\end{array}$ & $\begin{array}{c}\text { Post- } \\
\text { Test }\end{array}$ & $\begin{array}{c}\text { Pre- } \\
\text { Test }\end{array}$ & $\begin{array}{c}\text { Post- } \\
\text { Test }\end{array}$ & $\begin{array}{c}\text { Pre- } \\
\text { Test }\end{array}$ & $\begin{array}{c}\text { Post- } \\
\text { Test }\end{array}$ & $\begin{array}{c}\text { Pre- } \\
\text { Test }\end{array}$ & $\begin{array}{c}\text { Post- } \\
\text { Test }\end{array}$ & $\begin{array}{c}\text { Pre- } \\
\text { Test }\end{array}$ & $\begin{array}{c}\text { Post- } \\
\text { Test }\end{array}$ \\
\hline 68.55 & 85.65 & 79 & 88 & 4,790 & 7,353 & 85 & 95 & 65 & 80 \\
\hline
\end{tabular}

Table 2. Analysis of Pre-Test and Post-Test in the Experimental Group

A post-test was done by the researchers to measure the ability of the students in writing skills. The post-test was done on the students in the experimental class. This pre-test was done on Monday, October 11, 2021.

\begin{tabular}{|l|c|c|}
\multicolumn{1}{c|}{ The Data } & Pre Test & Post Test \\
\hline Cases Number & 26 & 26 \\
\hline Scores Sum & 1,782 & 2,227 \\
\hline Mean Score & 68.55 & 85.65 \\
\hline SD & 4,790 & 7,353 \\
\hline
\end{tabular}

Table 3. Comparison Description of Pre-Test and Post-Test in Experimental Group

\begin{tabular}{|l|c|c|c|}
\hline The Variable & The Mean & Difference of Mean & Improvement Percentage \\
\hline The Pre-Test & 68.55 & 17.10 & $19.96 \%$ \\
\hline The Post-Test & 85.65 & & \\
\hline
\end{tabular}

Table 4. Analysis of Students' Scores in Experimental Group

\begin{tabular}{|l|c|c|c|c|c|}
\hline \multirow{2}{*}{ Category } & \multirow{2}{*}{ Scores } & \multicolumn{2}{|c|}{ Frequencies } & \multicolumn{2}{c|}{ Percentage } \\
\cline { 3 - 6 } & & Pre-Test & Post-Test & Pre-Test & Post-Test \\
\hline Very High & $80-100$ & 0 & 10 & $0 \%$ & $41.67 \%$ \\
\hline High & $60-79$ & 22 & 14 & $84.62 \%$ & $58.33 \%$ \\
\hline Fair & $40-59$ & 4 & 0 & $15.38 \%$ & $0 \%$ \\
\hline Low & $0-39$ & 0 & 0 & $0 \%$ & $0 \%$ \\
\hline
\end{tabular}

Table 5. Descriptive Analysis of Pre-Test and Post-Test in Controlled Group

\begin{tabular}{|c|c|c|c|c|c|c|c|c|c|}
\hline \multicolumn{2}{|c|}{ The Mean } & \multicolumn{2}{|c|}{ The Median } & \multicolumn{2}{c|}{ SD } & \multicolumn{2}{c|}{ Max } & \multicolumn{2}{c|}{ Min } \\
\hline $\begin{array}{c}\text { Pre- } \\
\text { Test }\end{array}$ & $\begin{array}{c}\text { Post- } \\
\text { Test }\end{array}$ & $\begin{array}{c}\text { Pre- } \\
\text { Test }\end{array}$ & $\begin{array}{c}\text { Post- } \\
\text { Test }\end{array}$ & $\begin{array}{c}\text { Pre- } \\
\text { Test }\end{array}$ & $\begin{array}{c}\text { Post- } \\
\text { Test }\end{array}$ & $\begin{array}{c}\text { Pre- } \\
\text { Test }\end{array}$ & $\begin{array}{c}\text { Post- } \\
\text { Test }\end{array}$ & $\begin{array}{c}\text { Pre- } \\
\text { Test }\end{array}$ & $\begin{array}{c}\text { Post- } \\
\text { Test }\end{array}$ \\
\hline 62.00 & 71.75 & 66 & 66 & 3,943 & 5,180 & 78 & 84 & 45 & 62 \\
\hline
\end{tabular}

Table 6. Analysis of Pre-Test and Post-Test in the Controlled Group 
The Effect of The Google Classroom Application on The Students' Writing Skills in SMA Swasta Gajah Mada Medan During Covid-19 Pandemic, Irma Khoirot Daulay, Agnes Charismah Iman Putri Zendrato, Jeffry, Neslita Elisabeth Manik, Priska Simamora

\begin{tabular}{|l|c|c|}
\multicolumn{1}{|c|}{ Then Data } & Pre-Test Session & Post-Test Session \\
\hline Cases Number & 24 & 24 \\
\hline Scores Sum & 1,488 & 1,722 \\
\hline Mean Score & 62,00 & 71.75 \\
\hline SD & 3,943 & 5,180 \\
\hline
\end{tabular}

Table 7. Comparison Description of Pre-Test and Post-Test in Controlled Group

\begin{tabular}{|c|c|c|c|}
\hline The Variable & Mean & Difference of Mean & Improvement Percentage \\
\hline The Pre-Test & 62,00 & 9.75 & $13.59 \%$ \\
\hline The Post-Test & 71,75 & & \\
\hline
\end{tabular}

Table 8. Analysis of Students' Scores in Controlled Group

\begin{tabular}{|l|c|c|c|c|c|c|c|}
\hline \multirow{2}{*}{ Group } & \multirow{2}{*}{ Number } & \multicolumn{2}{c|}{$\begin{array}{c}\text { Level of } \\
\text { Significance }\end{array}$} & \multicolumn{2}{|c|}{$p$} & \multicolumn{2}{c|}{ Conclusion } \\
\cline { 3 - 8 } & $\begin{array}{l}\text { Pre- } \\
\text { Test }\end{array}$ & $\begin{array}{c}\text { Post- } \\
\text { Test }\end{array}$ & $\begin{array}{c}\text { Pre- } \\
\text { Test }\end{array}$ & $\begin{array}{c}\text { Post- } \\
\text { Test }\end{array}$ & Pre-Test & Post-Test \\
\hline $\begin{array}{l}\text { IX-IPA Class } \\
\text { as the } \\
\begin{array}{l}\text { Experimental } \\
\text { Group }\end{array}\end{array}$ & 26 & $5 \%$ & $5 \%$ & 0.532 & 0.462 & Normal & Normal \\
\hline $\begin{array}{l}\text { XI-IPS Class } \\
\text { as the } \\
\begin{array}{l}\text { Controlled } \\
\text { Group }\end{array}\end{array}$ & 24 & $5 \%$ & $5 \%$ & 0.105 & 0.243 & Normal & Normal \\
\hline
\end{tabular}

Table 9. Normality Test Result After Doing Pre-Test and Post-Test

\begin{tabular}{|l|c|c|c|c|c|}
\multicolumn{1}{|c|}{ Group } & W & df1 & df2 & $p$ & Interpretation \\
\hline $\begin{array}{l}\text { IX-IPA Class } \\
\text { as the Experimental } \\
\text { Group }\end{array}$ & 0.121 & 1 & 71 & 0.727 & Homogenous \\
\cline { 1 - 5 } \\
$\begin{array}{l}\text { XI-IPS Class } \\
\text { as the Controlled Group }\end{array}$
\end{tabular}

Table 10. Homogeneity Test Result (Pre-Test)

\begin{tabular}{|c|c|c|c|c|c|}
\hline Group & W & df1 & df2 & $p$ & Interpretation \\
\hline $\begin{array}{c}\text { XI-IPA } \\
\text { As the Experimental } \\
\text { Class }\end{array}$ & 1.353 & 1 & 71 & 0.245 & Homogenous \\
\hline $\begin{array}{c}\text { XI-IPS } \\
\text { As the Control Group }\end{array}$ & & & & & \\
\hline
\end{tabular}

Table 11. Homogeneity Test Result (Post-Test) 


\begin{tabular}{|c|c|c|}
\hline $\mathrm{F}$ & $\mathrm{df}$ & $\mathrm{p}$ \\
\hline 35.722 & 1 & 0.00 \\
\hline
\end{tabular}

Table 12. The Summary of the ANCOVA Results

From the result description after doing pre-test and post-test, The researchers can give some conclusions. From the data as presented in the table, it can be stated that the mean scores from the controlled group and experimental group were increased. By understanding the data, it can be explained that after the pre-test in the controlled and experimental groups was done, the control group's mean score was lower than the mean scores in the experimental group. The mean scores in the controlled group were increased by 3.41. The mean scores in the experimental group were increased by 12.05 .

After undertaking the normality test in this research, the researchers concluded that the students have a normal distribution for both the students in the controlled group and the experimental group. It can be seen that both groups have asignificance level that is higher than 0.05. The experimental class and the controlled group are homogenous. It can be concluded after knowing the result from the homogeneity test. The values of probability were higher than 0.05 . From this data, it could be concluded that the test was homogenous.

The significance level of ANCOVA (0.00) was known to be lower than 0.05. After knowing the result of this research, the researchers could conclude that the null hypothesis (Ho) can be rejected. Meanwhile, an alternative hypothesis (H1) can be accepted in this research. From the data, it can be stated that there is a significant effect on the students' writing skills after learning by using Google Classroom Application. Those students who were taught using conventional teaching methods also affected writing skills, but not significantly. Students who learned English in writing skills had a significant effect after using Google Classroom Application during the covid-19 pandemic.

\section{Conclusion}

The researchers propose some suggestions as follows: Firstly, English teachers are recommended to use Google Classroom Application when teaching writing skills, especially when having an online class. Secondly, students can use Google Classroom Application when joining online classes, especially when learning writing skills. Thirdly, other researchers are suggested to research using Google Classroom Application in teaching writing skills online. It is expected that the next researchers must have more exploration of the Google Classroom Application implementation when teaching writing skills to the students.

\section{References}

Alim, et. al. (2019). The Effectiveness of Google Classroom as an Instructional Media: A Case of State Islamic Institute of Kendari, Indonesia. Reviews of Humanities $\&$ Social Sciences.

Daulay, I. K. \& Asrul, N. (2021). The effect of media guessing game towards university students' writing ability on descriptive text local tourism content. English Review: Journal of English Education, 9(2), pp. 163-172. 
The Effect of The Google Classroom Application on The Students' Writing Skills in SMA Swasta Gajah Mada Medan During Covid-19 Pandemic, Irma Khoirot Daulay, Agnes Charismah Iman Putri Zendrato, Jeffry, Neslita Elisabeth Manik, Priska Simamora

Ela, Nur Laili \& Tatik, Muflihah. (2020). The Effectiveness of Google Classroom in Teaching Writing of Recount Text for Senior High Schools. Journal of Languages and Language Teaching (JOOLLT). October 2020. Vol. 8, No, 4.

Firdaus. (2020). Learning Describtive Writing With Local Tourism Destination Picture. Jawshiyah. Volume 15, Nomor 1, Hal. 1-27.

Gay, L.R. dan Diehl, P.L. (1992), Research Methods for Business and. Management. MacMillan Publishing Company, New York

Harmer, Jeremy. (2001). The Practice of English Language Teaching. Third edition. Longman Pearson Education Limited.

Johansson, M. (2021). Literary socialisation through education. A comparative study of Swedish and French upper secondary school students' reception of a narrative text. L1 Educational Studies in Language and Literature, (Special Issue Working with Literature in Nordic Secondary Education).

Liu, H. C., \& Chuang, H. H. (2016). Integrating Google Classroom to Teach Writing in Taiwan. Minnesota eLearning Summit.

M. Khalil, Zeiadee. (2018). EFL Students' Perceptions towards Using Google Docs and Google Classroom as Online Collaborative Tools in Learning Grammar. Applied Linguistics Research Journal.

Nation, I. S. P. (2009). Teaching ESL/EFL Reading and Writing. New York: Routledge.

Okmawati, Mike. (2020). The Use of Google Classroom During Pandemic. Journal of English Language Teaching. Universitas Negeri Padang.

Sidik, Mohammat. (2016). Dasar-Dasar Menulis Dengan Penerapannya. Malang: Tunggal Mandiri Publishing.

Sugiyono. (2013). Metode Penelitian Kuantitatif Kualitatif dan R\&D. Bandung: Alfabeta. 